\title{
8. From the First Fleet to 'Underbelly': Writing for the ADB
}

\author{
Gerald Walsh
}

I became acquainted with the Australian Dictionary of Biography half a century ago, in February 1961, when I was appointed a research scholar in historical geography in the Research School of Pacific Studies (RSPS) at the ANU. My task was to research the origins and development of manufacturing, or secondary industry, in Sydney, from its foundation to 1900. This involved identifying the manufacturers and industrialists - the flour millers, brewers, tanners, engineers, ironworkers, soap and candle makers, and textile manufacturers, for exampleand gathering information on the locations of their factories, the processes employed, the power used, and the duration of their establishments and the place of manufacturing in the emerging colonial economy. ${ }^{1}$

Anyone doing research in Australian history at that time was always sent along to have a yarn with L. F. Fitzhardinge, who had the somewhat grand title of 'reader in sources of Australian history'. My meeting with Laurie was most helpful. In conversations with him and other staff and students, I learnt about the existence of the Biographical Register that he had instituted in 1954 and about the two volumes then being prepared to cover the first period of the $A D B$ project, which would include, on the floruit principle, people who contributed to the Australian experience in the early colonial years, 1788-1850. Some of these people were my manufacturers and I soon realised that many manufacturers were also farmers, graziers, merchants and traders, which is not surprising considering that the emerging economy was very small and could not support much specialisation of economic activity.

\section{Early days}

In 1961 RSPS and the Research School of Social Sciences (RSSS), together with the library of the Institute of Advanced Studies (IAS), were housed in the wooden buildings of the old Canberra Community Hospital. These buildings are largely still there, on either side of Mills Road, except that what was then

\footnotetext{
1 For some of the results of my research into manufacturing, see G. P. Walsh, 'The English Colony in New South Wales: A. D. 1803', New Zealand Geographer, 18, no. 2 (1962), pp. 149-69; 'The Geography of Manufacturing in Sydney, 1788-1851', Business Archives and History, 3, no. 1 (1963), pp. 20-52; and Chapter 13, 'Manufacturing', in G. J. Abbott and N. B. Nairn (eds), Economic Growth of Australia 1788-1821 (Melbourne: Melbourne University Press, 1969).
} 
the library and the western wing of the main hospital building has given way to new buildings of the Research School of Earth Sciences. If you stand in front of the elegant portico (now heritage listed) of the old hospital, at the southern end of Mills Road, you can see where Douglas Pike, the first general editor, had his office, on the right-hand side next to the road, and Sir Keith Hancock, director of the RSSS, was on the left or Black Mountain side of the entrance. The main part of the hospital consisted largely of three wings parallel with the road, and the wing, verandah and lawn nearest to Black Mountain were where staff and postgraduate students met for morning and afternoon tea. In those pioneering days the relatively small academic body was a close community of scholars. In addition to Hancock, Pike and Fitzhardinge, and sometimes Manning Clark from the School of General Studies, there were, among others, Sir John Crawford (economics), Jim Davidson (Pacific history), Oskar Spate (geography), Mick Borrie (demography), Noel Butlin (economic history), Patrick Fitzgerald (oriental history), Pat Moran (statistics) and Geoff Sawer (law). It was at a morning tea that Nan Phillips, the energetic and efficient secretary who organised the $A D B$ office, introduced me to Douglas Pike, who was then still professor of history at the University of Tasmania and on one of his regular visits from Hobart.

At the time the $A D B$ was still in its planning stages and the list of persons to be included in the first few volumes was far from complete. Pike and the State working parties had little difficulty in getting established historians and specialist workers to write the articles on prominent figures, such as the early governors, explorers, politicians, judges, clergy and prominent settlers, but they often had trouble attracting authors for the less-prominent people: traders, merchants, farmers, minor civil and military officials and manufacturers. Pike expressed interest in my work and, always on the lookout for potential authors, asked me to contribute some entries.

I started my 48-year association with the $A D B$ by writing 19 articles (13 in Volume 1 and six in Volume 2), which were published in 1966 and 1967 respectively. Among the people I wrote about were the First Fleeters James Squire, convict, farmer and Australia's first commercial brewer, and Henry Hacking, quartermaster of HMS Sirius and explorer. Others were Benjamin Boyd, the flamboyant entrepreneur and pioneer of Twofold Bay, the Monaro and the Riverina; John Busby, engineer of Sydney's first regular water supply; John Dickson, who introduced steam power to Australia when he erected his steam mill on Darling Harbour in 1815; Sir John Jamison, physician, landowner and politician; David Jones, founder of the well-known retail firm; Mary Reibey, Australia's first businesswoman, whose portrait is on the $\$ 20$ note; and James Wilshire, commissary department official and tanner. Wilshire had the largest tannery in the colony, which operated from 1803 to 1860 on the site of the now Central Local Court and Brickfield Place in Liverpool Street, Sydney. 
The first article I completed and felt confident to submit was on Wilshire, the tanner. Pike commented on my first effort in the following letter:

\section{THE UNIVERSITY OF TASMANIA HOBART}

19-2-63

Dear Mr Walsh,

Mrs Phillips has sent a copy of your article on James Wilshire with a request for comments.

You have done a fine job on the man-his enterprise and energy come out clearly, in contrast to many articles where the man is lost behind a great mass of factual data. I think the prime question is - what will users look for in the Dictionary? Most will want specific information on dates and places, and a few will want a more general summary. If I'm right, then information becomes more important than interpretation, and that in turn raises the problem of word length. Your article could be edited down a little without sacrificing any substance at all, but even then would exceed the approximate span. I'm inclined to suggest, therefore, the deletion of such phrases of fact, on the grounds of relevance, as

Page 1. line 5 'under the recommendation of John Palmer'. line 10 'in place of William Neate Chapman'

12. 'during the ... Williamson'

18 'upon ... relieved'.

These names have some importance but do not directly bear on Wilshire's own personal story, in quite the same way as the reference to Nelson and Miss Pitt (p.2.1.2).

By editing, I mean nothing more than say-p.2. line 4- to reread-'By the bankruptcy of his English agent in 1811, he lost three years' salary and had to sell some land and cattle'. The picking up of 10 words or so here and there, without losing the point, make quite a difference. With articles that have no substance, the problem is frightening, but your work is a delight. I suggest that you have a chat with Pat $\mathrm{Croft}^{2}-$ she's very good and merciless on style. I hope this has helped. You leave me grateful. With my best wishes, Sincerely, Douglas Pike.

Pike's reference to style was no doubt justified, but finding his comments both useful and encouraging, I continued to finish the other 18 articles for

2 Pat Croft was a respected editor of ANU publications and, later, of ANU Press. See Shirley Purchase, 'Croft, Patricia (Pat) (?-1995)', ANU Reporter (16 August 1995), p. 11. 
the first two volumes and to suggest more manufacturers and other interesting characters I came across in the course of my research. And, of course, it was almost inevitable that if you found someone worthy who had been overlooked for inclusion, you were asked to write the entry.

\section{Historical research in the 1960s}

Doing historical research 50 years ago was very different from today. There was no quick, relatively cheap means of photocopying, and there were no computers, search engines or word processors. Note-taking was usually by hand on paper or cards and writing required a typewriter with carbon paper and correcting fluid. Library facilities were somewhat limited in Canberra, but were rapidly improving. The libraries of the IAS and the School of General Studies moved into their present buildings in 1963, but it was not until 1968 that the National Library of Australia (NLA) occupied its present handsome building on the shore of Lake Burley Griffin. Before this the NLA collections were dispersed at several locations: in Nissen huts at Scott's Crossing of the Molonglo River, at the western end of what is now King's Avenue Bridge; at Hume Circle in the suburb of Griffith; in the basement of the old Administration Building (now the Sir John Gorton Building) in Parkes Place; and even in (Old) Parliament House.

The Mitchell Library in Sydney, with which I was already very familiar, was, however, and still is, the great repository of early Australian history; it contained most of the vital sources for the majority of people included in the first six volumes of the $A D B$, covering the years 1788 to 1890 . Located in the original wing of the Public Library of New South Wales on the Macquarie Street side, it was also the then shopfront for the Archives Office of New South Wales. Although the Mitchell was small, with space for only about 30 readers at a time, its catalogue of printed books and manuscripts was excellent and crucial to the realisation of the $A D B$ project. This is evident in the source identification 'MS cat under [name] (ML)' that occurs in numerous early $A D B$ bibliographies. Another indispensable biographical source in the Mitchell was the 'Mutch Index', a comprehensive card index of the early settlers of New South Wales and Van Diemen's Land, compiled from convict indents, musters, land records and parish registers by the politician, historian and genealogist T. D. Mutch. There were some advantages to the researcher working in libraries and archives before modern technology made photocopying cheaper and before an increasing number of universities and students resulted in a greater demand for, and stress on, original source materials. You could peruse the early printed books and manuscripts (letters, diaries and private papers) in the original without 
using those never-fitting, cumbersome white gloves, and you could read all the newspapers in hardcopy, which is easier and quicker than viewing them on microfilm - though copying was not at the push of a button.

Certain sources, however, were only available abroad, as many of my biographical subjects had substantial links with the United Kingdom. When based in London during two long study-leave periods in the 1970s, I was able to research these connections using, among other collections, the marvellous resources of the British Museum (Library), the General Register Office (Somerset House), the Society of Genealogists (Kensington), the Public Record Office (then in Chancery Lane), the Institute of Historical Research, University of London, and the National Army Museum (Chelsea). Fieldwork, visiting cemeteries and such places as Cranbrook in Kent for the Tooth family, Sizergh Castle in the Lake District for the Stricklands, and East Grinstead, Surrey, for the financier Donald Larnach, was especially rewarding, as were visits to county and town archives, regimental museums, and Coalbrookdale in Shropshire, the cradle of the Industrial Revolution.

\section{Cemeteries as historical sources}

Most of the men and women included in the $A D B$ come from the lists compiled by the various working parties. Inevitably some worthy people have been missed from time to time, only to be suggested later by relatives or someone with special knowledge of a particular profession, trade or occupation. Interestingly, some who were overlooked originally were picked up from claims made on their headstones. This was especially the case with the people I was interested in and with minor figures. Cemeteries, with their tombstone epigraphy, especially in the eighteenth and nineteenth centuries, are veritable 'documents' in stone. Some monuments not only state name, dates of birth and death, occupation and names of family members, but also give a résumé of the deceased's life and a supposed claim to fame or remembrance.

The older headstones - much larger than modern ones - sometimes reveal the date of marriage, the country, county or town the person was 'native of', date of arrival in Australia, the person's educational qualifications, and the cause of death. The last mentioned was often recorded if it was the result of an accident, and especially if the person fell victim to one of the new means of transport, such as a train, steamboat, tram or motorcar accident. In these cases the name, number and a relief representation of the fatal vehicle were sometimes engraved on the stone - a vestige, perhaps, of the ancient law of deodand. Old cemeteries in general are landscapes of the past, survivals of a bygone age. They tell us much about the social history of their time - the mortality rate, the aspirations 
and achievements of the pioneers, artistic taste, and the strength of religious feeling. They provide evidence for the biographical historian otherwise not readily available. Cemetery epigraphy is a reminder that the art of biography, the history of the lives of individual men and women as a branch of literature, has its origins in the commemorative instinct, the impulse to defy annihilation.

Because I had long been addicted to 'reading' these landscapes of the past, I was able to make a somewhat singular contribution to the $A D B$ project. As a boy in Sydney, I lived not far from Rookwood Cemetery, the largest Victorianage cemetery in the world. ${ }^{3}$ Opened in 1868 and still in use, Rookwood was a product of the railway age. The bodies for burial, accompanied by mourners, were brought by train from Sydney and other stations along the western line to four mortuary stations within the cemetery, until 1948, when motor-vehicle funerals completely took over. My friends and I would ride our bicycles through the cemetery and through the most elaborate of these stations: Mortuary No. 1, which in the 1950s was sold, dismantled and reassembled as All Saints Anglican Church in the Canberra suburb of Ainslie. Eventually, in connection with my own research and biographical commitments for the $A D B$, I 'read' most of the old burial grounds in the Sydney metropolitan area. This was well before interested groups such as the 'friends of' various cemeteries began to take an interest, make systematic transcriptions of their epigraphy, clean them up, and conduct tours to the last resting places of the famous.

I will give two examples of informative tombstone inscriptions, one from 1822 and the other from 1927. The first is from the table-tomb of James Squire, the brewer, already mentioned. Originally in the old Devonshire Street (The Sandhills) Cemetery in Sydney, it was removed, like many of the graves, vaults and monuments, in 1901 to Bunnerong Cemetery, La Perouse, next to Botany Cemetery, to make way for Central Railway Station. ${ }^{4}$ I read and photographed it there more than 50 years ago. The inscription reads:

In Sacred Respect

to the Remains of

MR. JAMES SQUIRE,

late of Kissing Point,

who departed this life May 16th, 1822,

Age 67 Years.

He arrived in this Colony in the First Fleet,

and by Integrity and Industry

acquired and maintained an unsullied Reputation.

3 For a history of Rookwood Cemetery, see D. A. Weston (ed.), The Sleeping City: The Story of Rookwood Necropolis (Sydney: Society of Australian Genealogists/Hale \& Iremonger, 1989).

4 The Devonshire Street monuments at Bunnerong were removed to make way for an extension of Botany Cemetery in the 1970s. Squire's beautifully cut ledger stone has since disappeared. 


\author{
Under his Care \\ the HOP PLANT was first Cultivated \\ in this Settlement, and \\ the first BREWERY was Erected, \\ which progressively matured to Perfection. \\ As a Father, \\ a Husband, a Friend, and a Christian \\ He lived Respected and died Lamented. \\ Also JAMES SQUIRE, \\ Son of the above, \\ who Died MARCH 5th, 1826, \\ Aged, 28 years.
}

Squire had his brewery, tavern and 400 ha farm at Kissing Point, near Ryde, on the left bank of the Parramatta River, halfway between Sydney and Parramatta. Some might recall that Squire's reputation, name and rustic signature were resurrected in 1998 and given to a number of very good boutique-style ales, pilsener, porter and beer, produced in Sydney by the Malt Shovel Brewery Proprietary Limited at Camperdown.

The second is the substantial monument in Waverley Cemetery to the surgeon Thomas Henry Fiaschi, who died in $1927 .{ }^{5}$ It gives his degrees and decorations, stating that he was a doctor of both medicine and surgery from the universities of Pisa and Florence and that he was a brigadier general in the Australian Army Medical Corps, a companion of the Distinguished Service Order and a recipient of the Volunteer Decoration. It gives the dates and places of his birth and death, and lists other honours: Knight of St Maurice and St Lazarus, Italy, and Commendotore of the Crown of Italy. It also records that he was honorary surgeon of the Hawkesbury Hospital (1879-83), worked at the Sydney Hospital (1889-1912), and was honorary consulting surgeon at the latter from 1912 to 1927. Lastly, it tells us that he was president of the NSW Wine Association, 1902-27. Both these inscriptions, especially Squire's, are fairly representative of a type and their eras and yet, as Dr Samuel Johnson reminds us, 'in lapidary inscriptions a man is not upon oath'. The information had to be checked and tested. ${ }^{6}$

In addition to Squire and Fiaschi, among my many cemetery 'discoveries' whose entries I wrote for the $A D B$ were the following: William Bradley (1800-68) 'of Lansdowne Park, Goulburn and Bibbenluke, Monaro'; Sir Edward Strickland (1821-89) 'K.C.B., F.R.G.S. of the Noble Knightly Family of Sizergh Castle';

5 For an anecdote regarding Fiaschi, see my contribution, 'Grave History', in Peter Donovan (comp.), Adventures with Clio (Blackwood, SA: Donovan \& Associates, 1994), pp. 48-9.

6 R. W. Chapman (ed.) and Pat Rogers (intro.), James Boswell, Life of Dr. Johnson, London, 1791, Oxford World Classics (Oxford: Oxford University Press, 2008), p. 662. 
Henry Carter Perdriau (1817-92), 'One of the Leading Pioneers of Steam Ferry Transport on Sydney Harbour'; Bernard Bede Kieran (1886-1905), 'Late Champion Swimmer of the World'; James Thomas Allan (1831-1912), 'The Barcoo Pioneer and owner of Mount Enniskillen for 47 years'; and John Paton VC (1834-1914), '93 Sutherland Highlanders, Hero of Lucknow'. All the statements on their monuments proved to be true.

Bradley was one of the wealthiest landholders in New South Wales, a promoter of railways and a member of the Legislative Council. Strickland was a commissary officer who retired from the British army to live in Sydney. Author and promoter of geographical research, he was the one who suggested the sending of a contingent to the Sudan War in 1885. He was the uncle of Sir Gerald Strickland, first and last Baron Strickland of Sizergh Castle, Kendal, Westmorland, who, between 1904 and 1917 was successively governor of Tasmania, Western Australia and New South Wales. Perdriau, founder of the Balmain Steam Ferry Company Limited, was a member of a family prominent in the business life of Sydney. His eldest son, Henry, set up the Perdriau Rubber Company, later the Dunlop-Perdriau Rubber Company. Kieran, the greatest swimmer the world had seen, held every world record from 200 yards $(183 \mathrm{~m})$ to one mile $(1.6 \mathrm{~km})$, and many of his phenomenal times were not approached until many years after his death at the age of nineteen. Allan was a notable Queensland explorer and pastoralist based at Mount Enniskillen, near Tambo. At one stage his stations on the Barcoo River covered 4700 sq km. Known as 'Black Allan', he was a 'terror to cattle thieves and trade unionists'. Paton won his Victoria Cross during the Indian Mutiny in 1857. Soon after, he migrated to New South Wales and joined the prison service, finishing his career as governor of Goulburn Gaol. ${ }^{7}$

Among the many names and claims I investigated that were not included in the $A D B$ for reasons ranging from the insubstantial nature of their claims to the lack of any further supporting evidence, were: James Bryan (d. 1845), 'the first to introduce gas light into this part of the world'; Richard Murray, 'Cricketer of this City' (1861); William Vial, 'Who Saved the Life of the Duke of Edinburgh at Clontarf, March 12, 1868'; 'Professor' Charles Owen Peart, 'Champion high diver of the world' (1896); Sir John Cecil Read, 'Baronet' (1899); and Ernest James Card, 'Founder and Life Patron of the Society of Bricks' (1925). One tall, granite centennial family monument (1800-1900) in Rookwood Cemetery with an inscription beginning 'Robbery and Revolution Ruined Their Irish and French Estates Which were the operating causes of Their leaving England' looked promising but, on investigation, proved unrewarding.

7 The Perdriau, Allan and Paton graves are in Rookwood Cemetery; Strickland and Kieran in Gore Hill, St Leonards; and Bradley is in St Stephen's Churchyard, Newtown. 
Having espoused the value of cemeteries and gravestones as a possible source for $A D B$ aspirants, it is, to say the least, rather paradoxical that the occupant of what is perhaps the largest grave and monument in Sydney, and very likely in New South Wales, was overlooked. This was Michael Dwyer (1772-1825), the Irish revolutionary and political exile, 'The Wicklow Chief' of the 1798 Rebellion, who was reinterred with his wife in Waverley Cemetery from Devonshire Street in 1898. I, like many others, was very familiar with the beautiful, large marble monument with its tall Celtic cross, bas-reliefs, mosaics and metalwork, but not unnaturally assumed that Dwyer would be on the list for the first period. This was not so and the error was rectified in the $A D B$ 's supplement volume, edited by Chris Cunneen (with Jill Roe, Beverley Kingston and Stephen Garton) and published in $2005 .^{8}$

\section{Writing $A D B$ entries}

As I see it, the task of the biographer or mini-biographer is first to ascertain the relevant facts about the person's life and then by critical selection, imagination and, perhaps, artistry tell their story. But a full account can only be written if, according to the classical formula, you know a good deal about three things: what the person did; what the person thought and said; and what other people said about the person. For a full or 'three-dimensional' biography there must be adequate material from each of the three requisites.

Many people I wrote about for the $A D B$, especially in the early volumes, were what I call 'one or two-dimensional' characters. Very often you only knew what the person did, little or nothing about what they thought or said, and were short on contemporary assessments of their life to add colour to the biography. The First Fleeters Henry Hacking and James Squire are cases in point. Generally, with minor figures, the evidence supplied by contemporaries was rather terse. For example, Governor Philip King wrote of Hacking, who had been twice sentenced to death and reprieved: 'He is still a good Man and I am inclined to believe the last Crime was Committed to Obtain Spirits', and 'I am glad you have kept Hacking, he is a good man but was lost here by the Arts of a Woman'. In Squire's case, while much was known about his career, the only bit of colour was provided by a contemporary author and a fellow ex-convict. Peter Cunningham tells us that the 'jocose' brewer and proprietor of the celebrated halfway tavern at Kissing Point on the Parramatta River 'took pleasure in quoting' the epitaph in Parramatta churchyard of one of Squire's patrons:

8 Ruan O'Donnell, 'Dwyer, Michael (1772-1825)', in ADB, Supplement 1580-1980, p. 110. 
Ye who wish to lie here,

Drink Squire's beer! ${ }^{9}$

And Joseph Lycett, the forger, ex-convict and artist, wrote:

He was universally ... respected and beloved for his amiable and useful qualities as a member of society, and more especially as the friend and protector of the lower class of settlers. Had he been less liberal, he might have died more wealthy; but his assistance always accompanied his advice to the poor and unfortunate, and his name will long be pronounced with veneration by the grateful objects of his liberality. ${ }^{10}$

Such a tribute had to be used as it was all I could find.

It was sometimes easier to add colour to an entry if the subject was a politician. You could gauge from what they said as reported in parliamentary debates or Hansard something about their character and political stance: whether, for example, they were liberal or conservative, free trade or protectionist. In the days before modern political parties the test was what they said and how they voted on such key questions as electoral reform, industrial relations and the payment of Members of Parliament, but sometimes a search through parliamentary debates revealed nothing that could be used. Indeed, some politicians never spoke or asked a question in their whole parliamentary career. I remember the case of one pastoralist who uttered only 81 words in 12 yearsall on the one day. Not surprisingly, he asked what the government was doing about the rabbit problem!

Writing a 500-word entry on a minor figure is very often more difficult and time-consuming than preparing an article on a fully rounded, more important, 'three-dimensional' character. Usually, with the more important people, where sources abound, the problem is one of interpretation, condensation and deciding what details to omit. For the 'one and two-dimensional' figures the problem is finding enough material to build up a meaningful sketch of a person's life and work. In London I once kept a record of my research work and published an account of how I put together a 500-word article. ${ }^{11}$ All I had to start with were 17 words: 'John Francis Kempt, soldier, administrator of the government of New

9 P. Cunningham, Two Years in New South Wales: Comprising Sketches of the Actual State of Society in that Colony, of its Peculiar Advantages to Emigrants, of its Topography, Natural History, \& c., vol. 1 (London: Henry Colburn, 1827), pp. 91-2.

10 J. Lycett, Views in Australia, or, New South Wales \& Van Diemen's Land Delineated: In Fifty Views with Descriptive Letter Press (London: J. Souter, 1825), Letterpress accompanying Plate no. 8, 'Kissing Point, New South Wales', which shows Squire's brewery and farm.

11 The account of my researches, 'The Preparation of a Dictionary Entry: The Case of Colonel Kempt', was originally published in RMC Historical Journal, 2 (1973), pp. 25-30; it is substantially reproduced in Chapter 9 of Iain McCalman, with Jodi Parvey and Misty Cork (eds), National Biographies and National Identity (Canberra: Humanities Research Centre, 1996), pp. 123-33. 
South Wales, 22 January - 22 March 1861'. No dates of birth or death. I will not go into details here, but it turned out that Kempt could only have been completed using sources in London, and my account fairly well illustrates some of the difficulties in tracking down minor characters.

Among the entries on manufacturers, merchants and businessmen I wrote for the first 16 volumes of the $A D B$ were many on people who were household names over much of Australia, including Bushell, Farmer, Fowler, Foy, Hudson, Lysaght, Penfold, Peters, Playfair, Resch, Sands, Soul, Taubman, Toohey, Tooth, Vicars, Wormald and Wunderlicht. My research interests in Australian history widened when I began to teach a course on the history of science and technology in Australia. This led to invitations to write articles on natural scientists, inventors and people connected with agriculture and the pastoral industry. Sportsmen and women, especially swimmers and cricketers, have been another of my interests.

\section{Conclusion}

Forty-odd years after writing about James Squire, convict and First Fleeter, I was asked to write about another convict, George David Freeman (1935-90), 'criminal, gambler and racing commission agent', who appears in Volume 17. His story, along with others, was featured in 2009 in the first instalment of the popular and controversial television series 'Underbelly, a Tale of Two Cities', which dealt with organised crime in Sydney and Melbourne in the 1970s and 1980s.

Freeman was one of the most talked about alleged leaders of organised crime in New South Wales during a time of corrupt police and politicians. Accused of murder, assault, fixing horseraces, running illegal casinos and consorting with American crime figures, he was named in Parliament and royal commissions into organised crime, but his only convictions in the last 20 years of his life were two fines for illegal betting operations. According to one of his friends, the only thing he was never blamed for was the Newcastle earthquake. A colourful character, described by police as 'hard, smart and charming', Freeman had a degree of social acceptability despite his reputation. In 1988 he took the unusual step of publishing his autobiography in which he relates frankly and movingly his drift into juvenile crime, but is somewhat less satisfying on his later life. ${ }^{12}$ The worlds of the ex-convicts Squire and Freeman, born 180 years apart, were vastly different; nevertheless their stories are representative, part of the Australian experience, and so rightly have their place in the $A D B$. 
Writing for the $A D B$ has helped me to realise how much I did not know about Australia, and recognising how much you do not know is an essential part of any education. From the professional point of view as a university teacher of Australian history, it has been a preparation and enrichment that could not have been bettered. The $A D B$ is the great repository of the Australian identity. The value of accessible, definitive biographies of the major figures in our history needs hardly be stressed, but they are only part of the picture. The lesser known, often only 'one or two-dimensional' figures also have their place, and because they are included we have a fuller, truer picture of Australia's past. In most histories the common persons' achievements, while omnipresent and undisputable, are muted and obscured in a collective anonymity. The $A D B$ represents that essential corrective in Australian historiography.

While I have written about the lives of important figures who could be the subjects of full biographies - and some have been - I have concentrated mainly on the lesser known, knockabout and shadowy minor characters. I have been pleased to suggest and to write the biographies of a swagman, a rabbiter, a shearer, a whip-maker, horse-breakers, sheep-classers, sheepdog breeders, a rugby union coach, a singer, a gold-seeker, an outlaw, 'The Flying Pieman', the inventor of the shearing machine, Australian VC winners, and the most famous Anzac of all! ${ }^{13}$ It has been a fascinating and most interesting experience. I have enjoyed the journey immensely.

Dr Gerry Walsh is preparing for publication the third volume of his series beginning with The Bush and the Never Never (2004), dealing with significant but neglected aspects of Australian rural history and technology.

13 The gold-seeker was H. B. Lasseter, the outlaw was Jimmy Governor and 'The Flying Pieman' was William Francis King. F. Y. Wolseley was the inventor of the shearing machine, and the most famous Anzac of all is John Simpson Kirkpatrick, 'The Man with the Donkey'. 


\section{Profile}

\section{Gerry Walsh (b. 1934)}

Gerry Walsh is the $A D B$ 's most prolific author, having written, up to 2013, 195 entries (and a chapter for this book). A former cricket coach, administrator and umpire, he has been fittingly described as the 'Don Bradman' of the $A D B$. He is a graduate of the University of Sydney (BA, 1956; DipEd, 1957; MA, 1960) and ANU (MA, 1970), and was a lecturer/senior lecturer in history (1966-2001) in turn at the Royal Military College of Australia (Duntroon), the Faculty of Military Studies, University of New South Wales at Duntroon, and, from 1986, at the Australian Defence Force Academy, University College, UNSW, Canberra. He has been associated with the $A D B$ for more than 50 years, first as a research assistant for six months in 1964, then as a member of the NSW Working Party for 20 years - his knowledge of manufacturing in nineteenth-century Sydney was very much appreciated - and as an author. His books, which reflect his work for the $A D B$, include Pioneering Days: People and Innovations in Australia's Rural Past (1993), Australia: History and Historians (1997), The Bush and the Never Never (2004), Born of the Sun: Seven Young Australian Lives (2005) and On the Wallaby (2005). He also introduced and taught a course at ADFA on the history of science and technology in Australia.

Source: Citation for $A D B$ Medal for Gerry Walsh (11 October 2002), NCB/ADB files. 
The ADB's Story

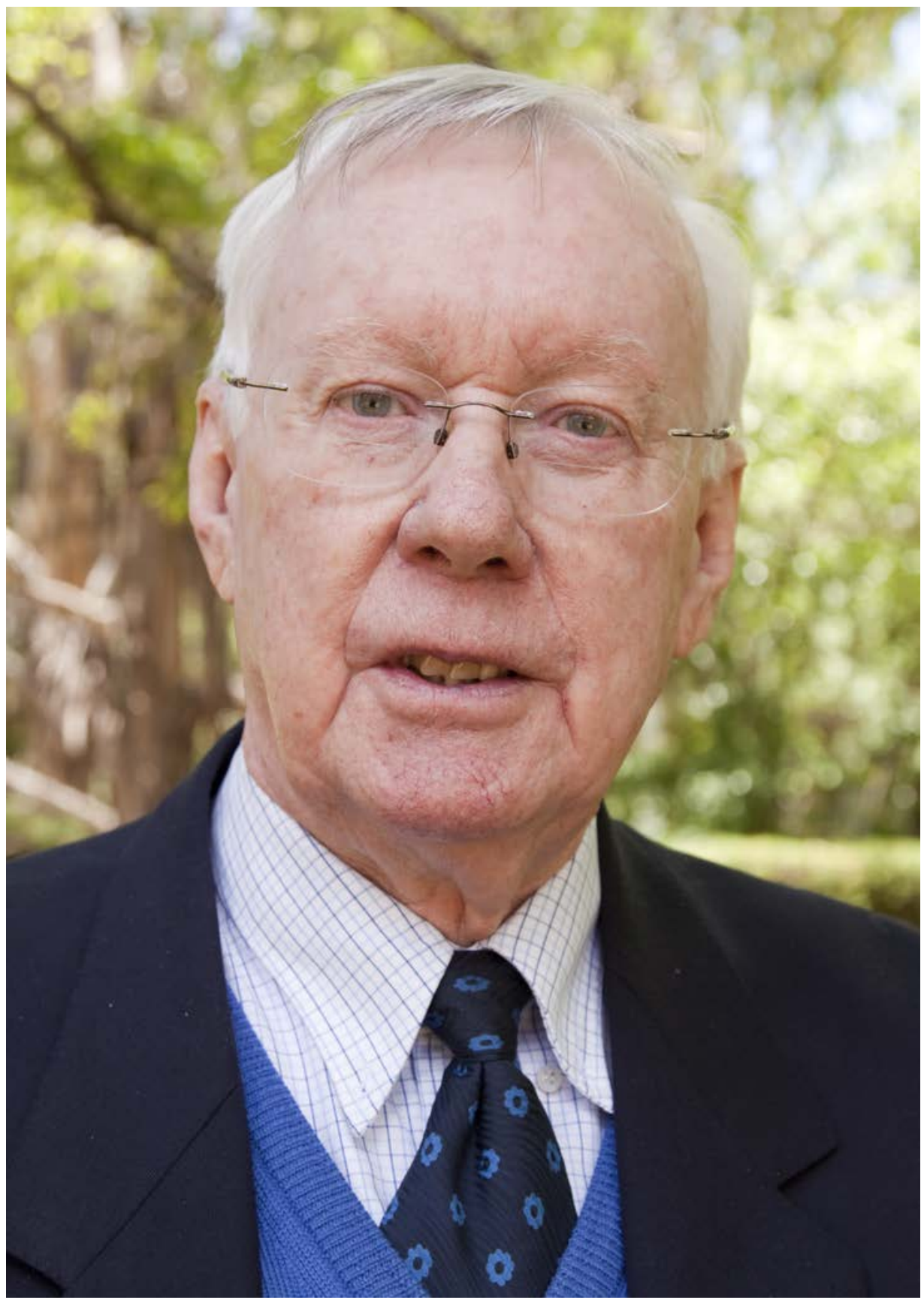

Gerry Walsh, 2009

Photographer: Peter Fitzpatrick, $A D B$ archives 


\section{Profile}

\section{Ann Hone (b. 1939)}

Ann Hone, after graduating from the University of Melbourne (BA Hons, 1961), undertook graduate study at Monash University (MA, 1965) with Geoffrey Serle as her supervisor. In 1975 the University of Oxford awarded her a DPhil for a thesis on London radicalism, 1796-1821, which was later published by Oxford University Press as For the Cause of Truth: Radicalism in London, 1796-1821 (1982). From 1973 to 1996, she lectured in the faculty of education, University of Canberra, and from 1996 to 1999 she was dean of students at Ormond College, University of Melbourne.

Hone's association with the $A D B$ began with a 10-month stint (including three months in Canberra) as a research assistant in 1965. During the next few years she wrote 65 entries, all 500-worders. Later she reconnected with the $A D B$ : as a member of the Commonwealth Working Party, she particularly enjoyed her special brief to search the Commonwealth Scientific and Industrial Research Organisation (CSIRO) records for possible subjects. Interestingly, both her father, Sir Brian Hone, and her grandfather, Frank Sandland Hone, have entries in the $A D B$.

Source: Ann Hone to the $A D B$ (31 July 2012), NCB/ADB files.

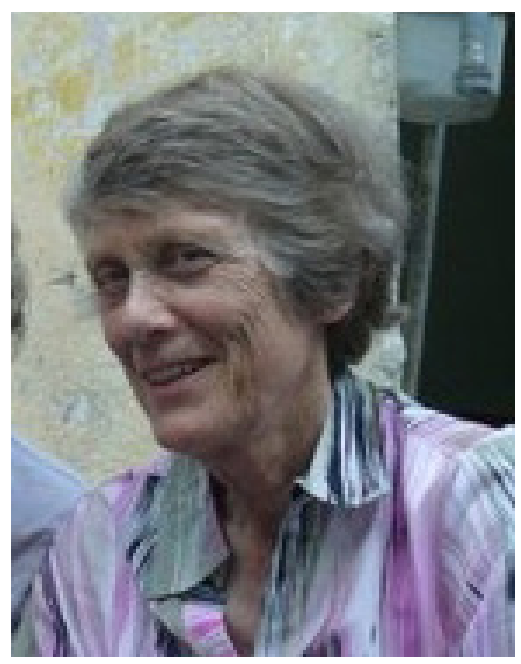

Ann Hone, n.d.

By courtesy of Ann Hone 
The ADB's Story

\section{Profile}

\section{Ken Cable (1929-2003)}

Ken Cable's work for the $A D B$ spanned its first 50 years, from 1960 when he was selected as a provisional section editor. He was drawn into the $A D B$ at the outset because of his expertise in the history of church and state, his professional standing, and his enthusiasm for biography. He had graduated with first-class honours and the university medal in history from the University of Sydney (BA, 1949; MA, 1954) and had travelled to Britain, where he took a degree at King's College, Cambridge (BA, 1954). Appointed first as a history lecturer at the University of New South Wales, he transferred to the University of Sydney in 1958. He served as head of department (1986-89) before retiring in 1989. Cable, who joined the NSW Working Party in mid 1962, was a member during the preparation of Volumes 1-13. He was on the National Committee for Volumes 6-9, on the Editorial Board for Volumes 6-12, and was NSW section editor for Volumes 7-12. His wide-ranging interests were very useful to the working party: he spoke authoritatively on national, state, church and university politics, education at all levels, the arts, the legal profession, architecture, railways and cricket. Fellow members remember him for his geniality and wit. He wrote $74 A D B$ entries on bishops, clergy and prominent laymen of the Church of England, on significant figures of the University of Sydney (Professors John Woolley and Mungo MacCallum) and on cricketers such as Stan McCabe. ADB staff appreciated his readiness to provide elusive ordination dates and other details from his meticulously kept card index of Anglican clergy, which he prepared with his wife, Leonie; the Cable Clerical Index is now online.

Source: Brian Fletcher, 'Dr Ken Cable AM, 1929-2003: A Memoir', Journal of the Royal Australian Historical Society, 89, no. 2 (December 2003), pp. 103-6. 
8. From the First Fleet to 'Underbelly': Writing for the ADB

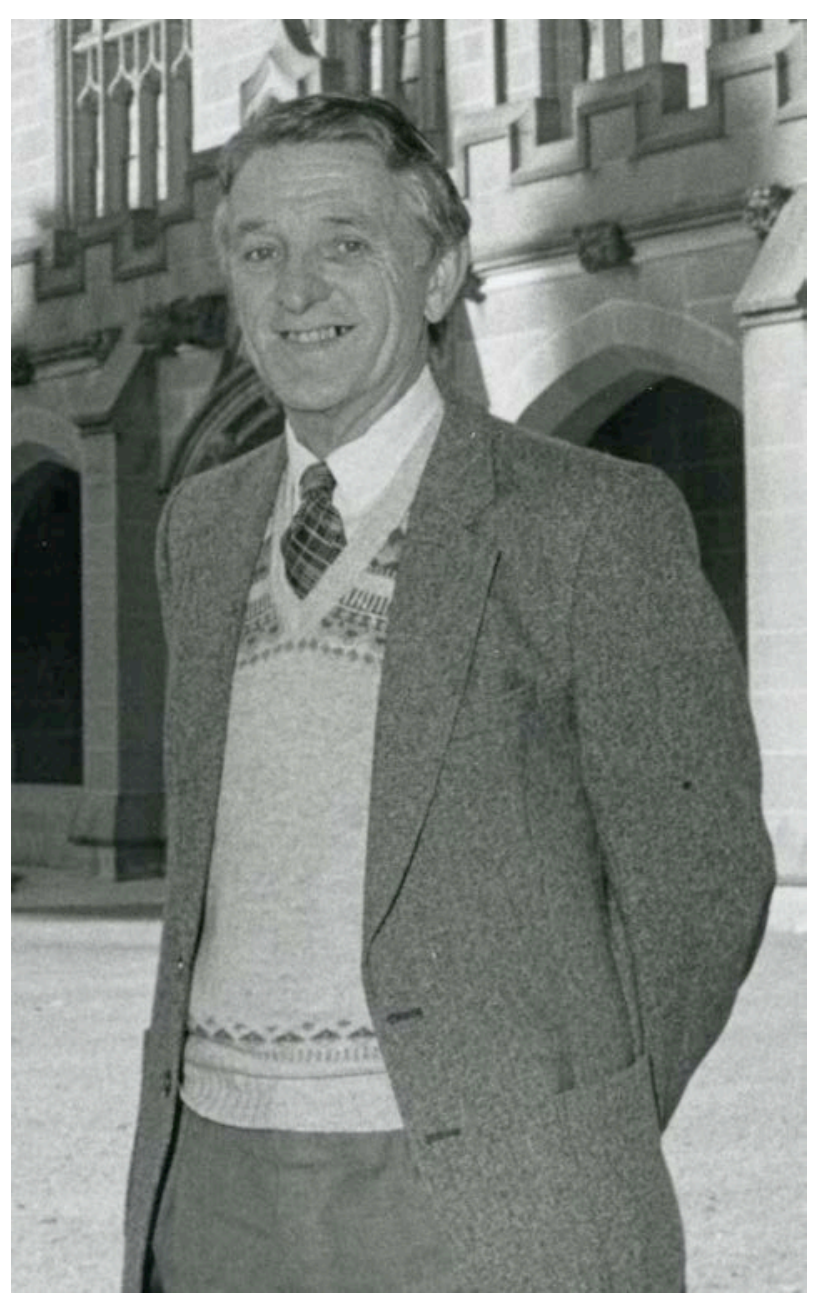

Ken Cable, 1985

University of Sydney Archives, G77_1_1069 
The ADB's Story

\section{Profile}

\section{Martha Campbell (b. 1936) and Suzanne Edgar (b. 1939)}

Between them, Martha Campbell and Suzanne Edgar worked for the $A D B$ for nearly 65 years - Campbell from 1967 to 2002 and Edgar from 1969 to 1998. Their working lives spanned many of the changes that have occurred at the $A D B$. Campbell, a graduate of the University of Sydney (BA, 1959) and ANU (MA, 1966), observed that her job had evolved 'like Topsy'. Under Douglas Pike, she wrote entries; under later general editors, she 'subedited and checked'. When the editing was delegated under Nairn and Serle, she took charge of the NSW desk, the largest of the State desks. As the 1986 review noted, 'editing' is a modest term for procedures that at times prompt considerable new research and in all cases involve careful checking back to original source materials. Described as the 'doyen of research editors', Campbell mentored a succession of new staff members. She remained at the NSW desk until her retirement. Under the name Martha Rutledge, she wrote a total of 172 entries.

Edgar was a graduate of the University of Adelaide (BA Hons, 1962), where she was a student of Pike's. Like Campbell, she started at the $A D B$ as a 'traditional fact-finding research assistant' until taking on the SA desk and also, at various times, some of the smaller State desks. She has written 53 entries. She resigned in 1998 and is now well known in Canberra as a full-time writer and poet.

Sources: 'Editorial Staff-The Research Assistants-At the ADB. To be Presented to the Committee of Review, February 1985', signed by Suzanne Edgar, Helga Griffin, Dr Di Langmore, Merrilyn Lincoln and Dr Margaret Steven, box 125, Q31, ADBA, ANUA. Suzanne Edgar, interviewed by Niki Francis and Melanie Nolan (22 June 2012), NCB/ADB files. 


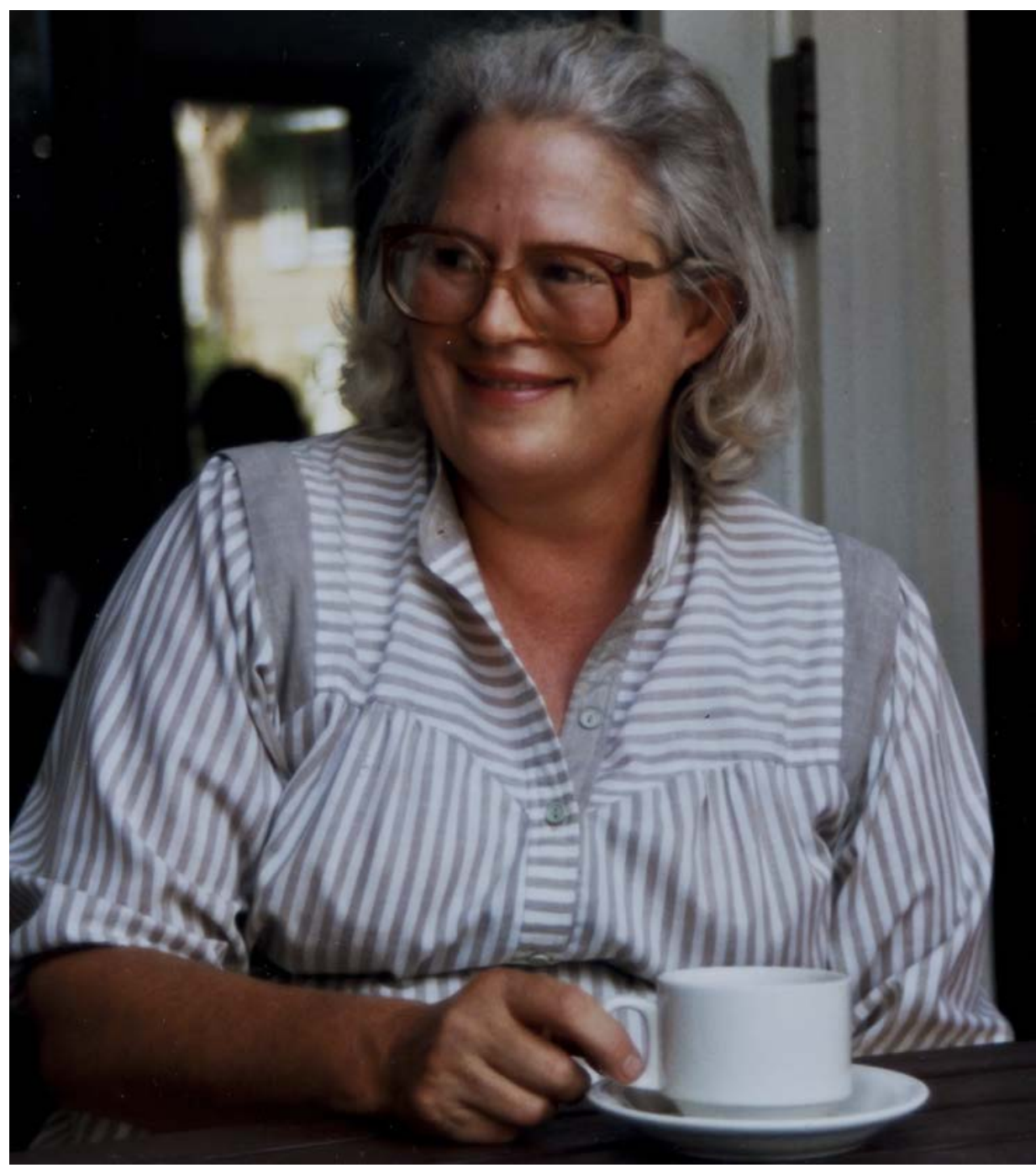

Martha Campbell, 1985

By courtesy of Sue Edgar 
The ADB's Story

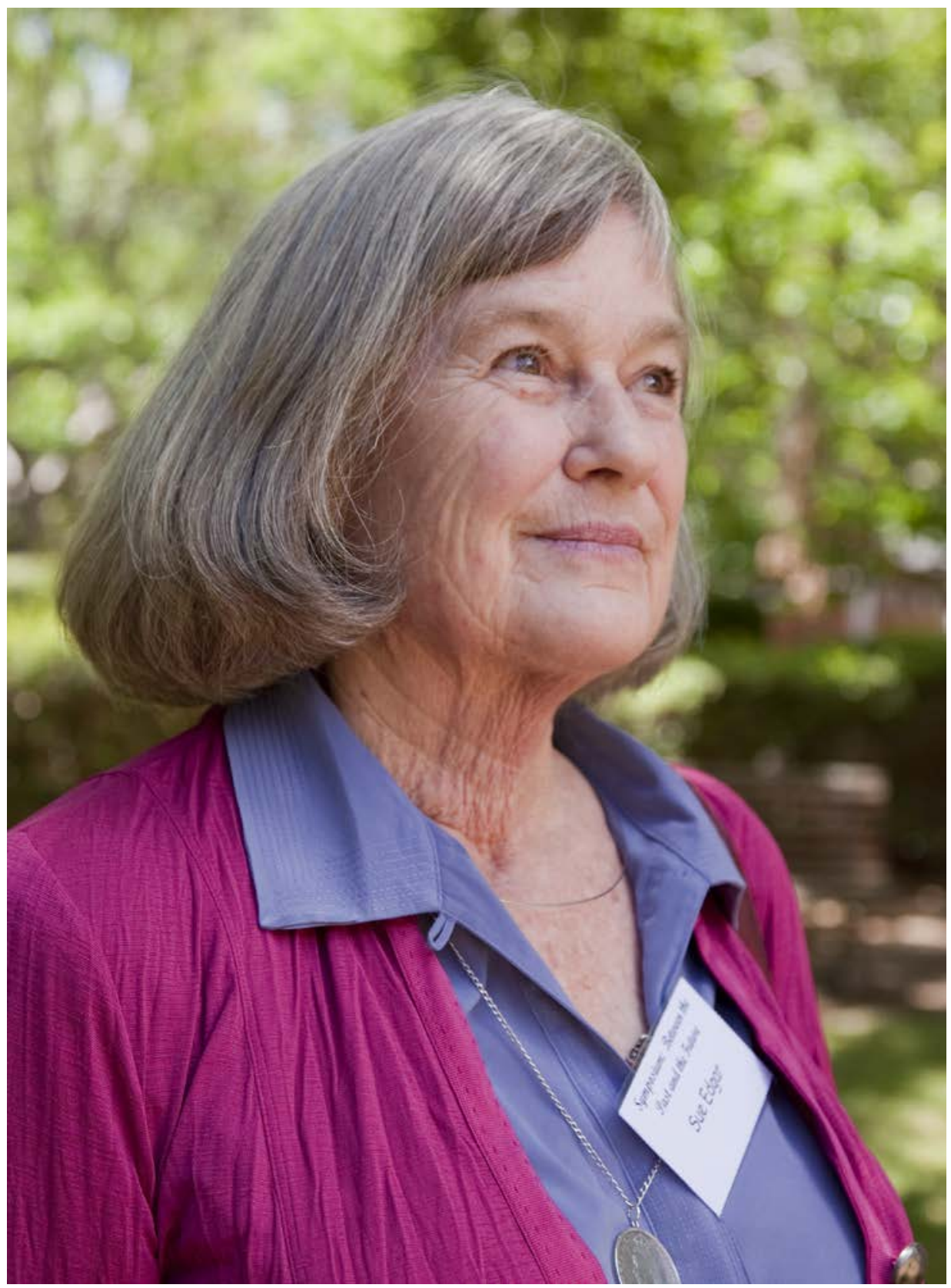

Sue Edgar, 2009

Photographer: Peter Fitzpatrick, $A D B$ archives 


\title{
A King's Remains
}

\author{
by Suzanne Edgar
}

Sue wrote the ADB entry on Albert Augustine Edwards, (1888-1963), hotelier, philanthropist and politician and later wrote this poem about him.

Every little while,

In tracking past obsessions,

I sift through dusty files

and find in my possession

a story in the archive

of characters long dead;

like bees in summer hives,

they once flew round my head.

It's how I read today

of Bert, a Labor 'pollie'

who honed his willful ways

to the point of shameless folly.

Though the newspaper has yellowed

and its print is not as black

this maverick hasn't mellowed,

his ploys come rushing back.

As King of the wild West End

he fiddled ballot books,

said rules were made to bend

and went to bed with crooks.

He made a heap of dough

and ran a shelter for the poor

while never slow to show

the rent-boys through his door.

When the King came to die

he had himself embalmed:

you have to wonder why

there was no one to be charmed. 
The ADB's Story

The subtle old knave

was in a copper-lined box

when lowered to his grave-

one lad threw down some rocks

Last year they disinterred him

to take samples of his tissues

the need was dark and grim

to settle several issues,

like who was this man's father,

the premier or a pimp?

Bert claimed it was the former

though his case is looking limp.

Members of the press

and historians gathered round

the controversial mess

In the grave-site's opened ground.

That's why I love my files-

old stories will revive

and villains with their wiles

rise up and come alive.

The poem is reprinted from Quadrant, 55, no. 11 (November 2011). It was also selected by Les Murray (ed.) for inclusion in his best of the crop from the past 10 years: The Quadrant Book of Poetry (Quadrant, 2012). 


\title{
The $A D B-$ My Best Friend
}

\author{
P. A. Selth
}

Earlier this year I casually remarked to an $A D B$ staff member that the Australian Dictionary of Biography was 'my best friend', and in various ways had been part of my life for longer than I cared to remember. I was promptly asked to put this in writing.

My father, Don, had a history degree from the University of Adelaide. There were four students in his honours year; one of them was Douglas Pike. In 1959 our family moved from Adelaide to Launceston when Dad became headmaster of the Launceston Church of England Grammar School. Dad wanted to increase the amount of attention given in the school curriculum to Australian history, in particular the history of Tasmania. The main problem was the curriculum set by external examination bodies. He set about having it changed. He had an ally: Doug Pike was appointed to the chair of history at the University of Tasmania in 1960, and became foundation general editor of the ADB on 31 January 1962. ${ }^{14}$

There were then few books about Tasmania's history. Dad had a copy of John West's The History of Tasmania (1852), and he arranged for a copy of the Libraries Board of South Australia's 1966 facsimile edition to be placed in the school library. ${ }^{15}$ (Multiple copies of A. G. L. Shaw's wonderful 1971 edition were also to be added to the library's growing collection of books on Australian history.) Dad taught a Tasmanian history class. Our textbook was J. R. Skemp's dark-green, limp-cloth-covered Tasmania Yesterday and Today, published in 1958. ${ }^{16}$ It was all fairly rudimentary; there was not much readily available for the teaching of secondary school students (or anyone else), despite our teacher's passion for the subject.

Things changed in 1966. Volume 1 (1788-1850, A-H) of the $A D B$ appeared in the shops. Dad soon brought home the beautifully produced red-cover, cream-dust jacket volume - and we discussed who got to read it first. I lost, but we jointly looked for entries of men and women who had a connection with Tasmania (and South Australia). I remember our finding the entry for Joseph Archer, the Tasmanian landowner, some of whose descendants were at the school. ${ }^{17}$ And there was the bushranger Matthew Brady, whose alleged hide-out near Launceston we had been shown on a school excursion. ${ }^{18}$

14 Bede Nairn, 'Pike, Douglas Henry (Doug) (1908-1974)', ADB, vol. 16, pp. 1-2.

15 John Reynolds, 'West, John (1809-1873)', $A D B$, vol. 2, pp. 590-92.

16 Gwenda M. Webb and Peter G. Webb, 'Skemp, John Rowland (1900-1966)', ADB, vol. 16, pp. $253-4$.

17 G. T. Stilwell, 'Archer, Joseph (1795-1853)', $A D B$, vol. 1, pp. 24-5.

18 L. L. Robson, 'Brady (Bready), Matthew (1799-1826)', ADB, vol. 1, pp. 147-8. 


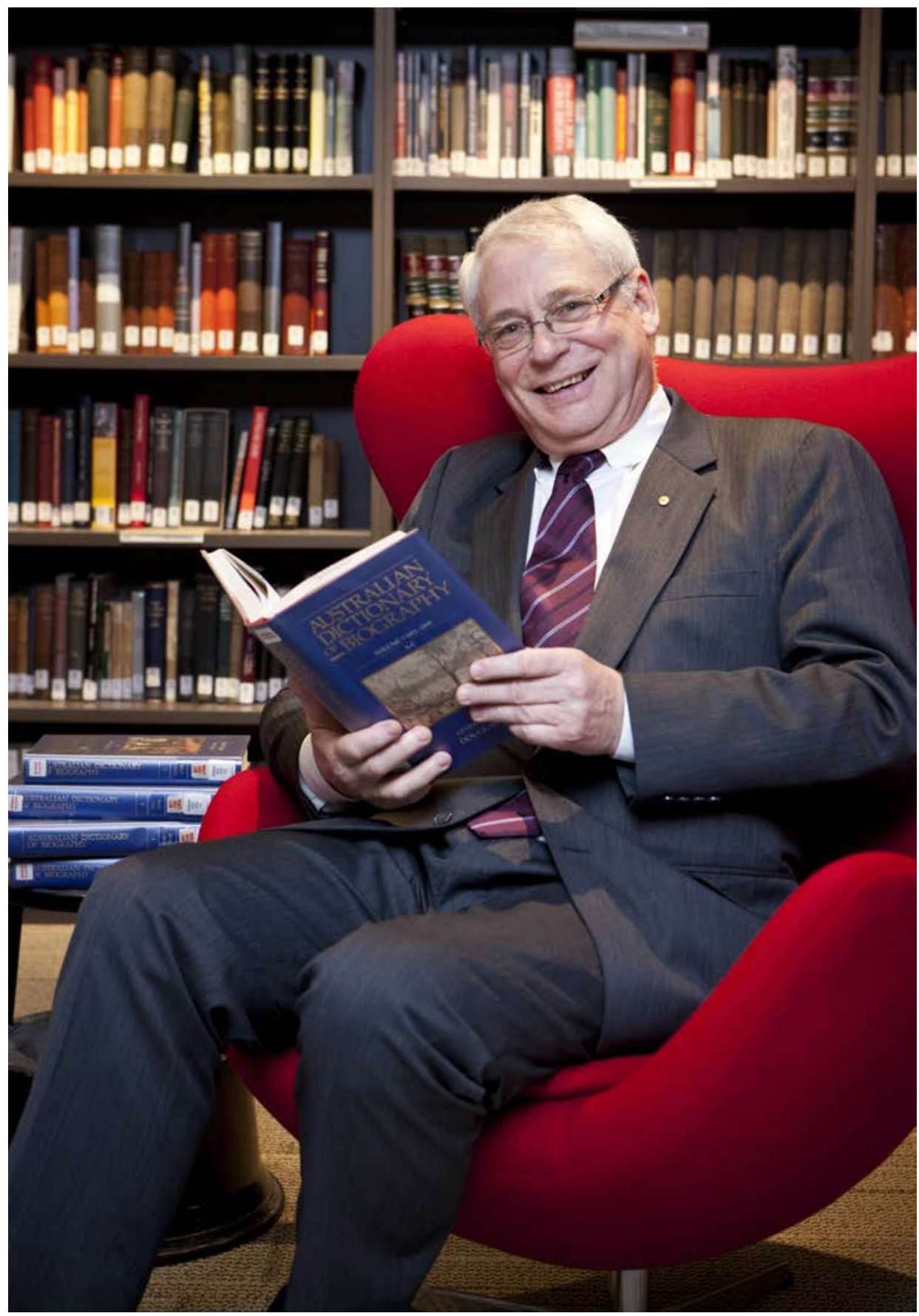

Philip Selth with his beloved editions of the $A D B, 2012$

By courtesy of Philip Selth 
The advent of the $A D B$ did not help me in my study of history at school, for by now I was required to learn about the kings and queens of England, but I had the $A D B$ at home and read it avidly. In the end Dad gave up, and bought me my own copy of Volume 1 (and Volume 2 in 1967).

I went to the ANU in 1968 to study Australian history and political science. A few years earlier Dad had given me a copy of Fin Crisp's Ben Chifley: A Biography $(1961)^{19}$ and Manning Clark's A History of Australia. Volume 1: From the Earliest Times to the Age of Macquarie (1962). Now I had access to wonderful libraries on the campus and across the lake where the National Library of Australia was opened later that year. Like many students then, I had a Commonwealth Scholarship - and little money. But I was at the Co-Op Bookshop on the day Volume 3 of the $A D B$ was available - and I bought Dad a copy. I was to give Dad a copy of each volume as it came out. He was reading the Supplement 1580-1980, published in 2005, when he became too ill to continue to read. His set of the $A D B$ went to a grateful grandson.

The ANU's history and political science departments at that time were filled with lecturers such as Manning Clark, Don Baker, Eric Fry, Barbara Penny, Dorothy Shineberg and Fin Crisp, who inspired their students and made frequent references to the $A D B$. Not surprisingly, most had written entries for the dictionary. John Ritchie, whom I still remember giving a wonderful oration in the Tank lecture theatre on Governor Macquarie, his black academic gown astray, was to become general editor of the $A D B$ in 1988 . We lived near each other, and on occasion met at the Belconnen Trash and Treasure Market where, among other matters, we would talk about the forthcoming volume of the $A D B$ or the book on which he was working, The Wentworths: Father and Son (1997). John would invariably have to counsel me to wait patiently for the next volume - it would not be published until he was satisfied it was in the best possible form.

While at the ANU I joined the Canberra and District Historical Society and met three of the $A D B$ 's greatest supporters: Nan Phillips, ${ }^{20}$ Pat Wardle ${ }^{21}$ and Don McDonald. ${ }^{22}$ Nan was the society's long-serving secretary, Pat the editor of its Newsletter, while Don edited its Journal. Nan was personal assistant to the $A D B^{\prime}$ s general editor; Pat had assisted in the early work of the Biographical Register, the forerunner to the $A D B$; all three were contributors. All three deserve entries

19 Scott Bennett, 'Crisp, Leslie Finlay (1917-1984)', ADB, vol. 17, pp. 269-70.

20 Suzanne Edgar and Martha Campbell, 'Phillips, Nan (1911-1984)', Obituaries Australia, National Centre of Biography, The Australian National University, Canberra, <http://oa.anu.edu.au/obituary/phillipsnan-814/text815> (accessed 26 June 2012) (f.p. ANU Reporter [May 1984], p. 6).

21 George Temperly, 'Patience (Pat) Australie Wardle, nee Tillyard (20 June 1910 - 22 April 1992): 'A Lover of Nature, a Ministering Angel and a Friend to All', Canberra Historical Journal, [NS] no. 30 (1992), pp. 5-7. 22 P. A. Selth, 'Donald Ian McDonald 1923-1990: “A scholar and a gentleman": A Memoir', Canberra Historical Journal, [NS] no. 27 (1991), pp. 12-20. 
in the $A D B$; both of Pat's parents, and her husband, are already there. ${ }^{23} \mathrm{I}$ also remember, with fondness, Jim Gibbney, both in his room in the $A D B$ offices, squinting over his collection of file cards of biographical references, which so many of us regarded as an Aladdin's cave of delights, and at his kitchen table with a glass of whisky, arguing over my suggestions for his $\mathrm{PhD}$ thesis that was to be published as one of a three-volume history of the Australian Capital Territory. ${ }^{24} \mathrm{Jim}$ also deserves an entry in the $A D B$ or, as he used to call it, 'the Dic'.

Don McDonald was succeeded as the Journal's editor in December 1971 by John Iremonger; I became editor in March 1976. From 1990 to 1993, John was the $A D B$ 's publisher at Melbourne University Press. I remember discussing with him what I thought to be a dreadful decision - the replacing of the lovely cream dust jacket with the current glary blue jacket. 'Comrade', he said, 'it gets the customer's eye'. He wanted to introduce the $A D B$ to a wider readership; I just wanted to read it. He gave me a full set of the blue jackets and instructed me to put them on my volumes of the $A D B$; I did-over the cream jacket.

I have three entries in the $A D B$, and am trying to draft three more. ${ }^{25}$ I cannot remember who asked me to draft the first two (probably John Ritchie). Chris Cunneen asked me to write the next two. I volunteered myself for the two that will follow. The entry on the barrister Eric Miller inspired me to begin work on two full-length biographies, of Eric Miller QC and of his cousin John Joseph Murphy (1914-97), New Guinea patrol officer, Coastwatcher, POW and PNG district officer. The $A D B$ has been the genesis of literally hundreds of articles and books, and is cited in any scholarly work on Australian history. ${ }^{26}$ It has also been the 'cause' of many of its readers, not least me, spending more than we perhaps should to purchase books cited in entries or written by contributors.

23 K. R. Norris and D. F. Waterhouse, 'Tillyard, Robin John (1881-1937)', ADB, vol. 12, pp. 232-3. Patricia Clark, 'Tillyard, Pattie (1880-1971)', $A D B$, vol. 12, p. 232. Barbara Dawson, 'Wardle, Robert Norman (1895-1979)', $A D B$, vol. 16, p. 491. An entry for 'Wardle, Patience Australie (Pat), née Tillyard (1910-1992), Community Member/Worker', is scheduled for publication in the 1991-95 volume.

24 Jim's cards formed the basis of H. J. Gibbney and Ann G. Smith (eds), A Biographical Register 1788-1939: Notes from the Name Index of the Australian Dictionary of Biography (Canberra: Australian Dictionary of Biography, 1987). H. J. Gibbney, Canberra 1913-1953 (Canberra: Australian Government Publishing Service, 1988). Obituaries for Jim include Chris Cunneen, 'Obituary Jim Gibbney', The Canberra Times (26 August 1989), p. 6; 'Obituary, Dr H. J. Gibbney, 1922-1989', Historical Records of the Australian Capital Territory (Canberra: Canberra District Historical Society, 1990), pp. 4-5. See also, posthumously, 'Launching of Jim Gibbney's Historical Records of the Australian Capital Territory. A Guide', Canberra Historical Journal, [NS] no. 27 (1991), pp. 48-9.

25 P. A. Selth, 'Pottinger, Sir Frederick William (1831-1865)', $A D B$, vol. 5, pp. 451-2; 'Piper, Harold Bayard (1894-1953)', $A D B$, vol. 16, p. 6; 'Miller, Eric Stanislaus Joseph (1903-1986)', $A D B$, vol. 18, p. 161. 'Kevin Ross Murray (1931-1991), barrister and army officer', 'Daniel Leahy (1912-1991), explorer and pioneer' and 'W. J. Read (1904-1992), Coastwatcher and government officer' are scheduled for publication in the volume covering the period 1991-95.

26 As happened with so many other contributors, I was encouraged by Don McDonald and Nan Phillips to expand my entry on Sir Frederick William Pottinger into an article: "A splendid type of the genuine English gentleman": Sir Frederick William Pottinger, Bart. (1831-1865)', Canberra Historical Journal (March 1974), pp. 20-53. 
I returned to the ANU in January 1992 as pro vice-chancellor (planning and administration). It was not long before I was wandering lost about the Coombs Building looking for the $A D B$ offices. (I had been there dozens of times, but the catacombs-like Coombs Building is not exactly visitor-friendly.) I was greeted like a long-lost friend (as I would like to be regarded) of the $A D B$ - and promptly asked if I could help solve a problem. It was thought I may have some influence. The request was reasonable and the $A D B$ did indeed have a friend in the Chancellery Building. More importantly, it had many across the campus, throughout Australia, and abroad.

As I try to write the two biographies for which I 'blame' (thank) the $A D B$, I refer daily to the $A D B$ online; but only to find the references - I then prefer to sit in a chair in a quiet place reading the bound volume. My son, however, probably has not picked up a bound volume. Like many of his generation, he reads the $A D B$ on a hand-held device. But that does not matter. What matters is the existence of the $A D B$ and the scholarship, and pleasure, it has brought so many people.

I am glad that the $A D B$ is my best friend.

Philip Selth OAM is executive director of the New South Wales Bar Association. His ADB entry on the Sydney silk Eric Miller QC (1903-86) has led him to work on two full length biographies, one on Miller and the other on his cousin, John Joseph Murphy (1914-97), a coastwatcher charged with treachery after being released from a Japanese prison camp. Philip is also writing the ADB entry on Murphy. 